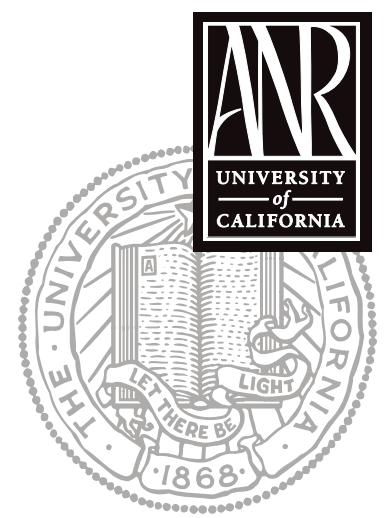

UNIVERSITY OF CALIFORNIA

Division of Agriculture and Natural Resources http://anrcatalog.ucdavis.edu

\title{
Introduction to Genetic Modification
}

PEGGY G. LEMAUX, Cooperative Extension Specialist, Department of Plant and Microbial Biology, University of California, Berkeley

Genetic modification of plants and animals by sexual crossing has been taking place for thousands of years. It began when humans decided to stay in one place rather than move from place to place in search of food. To increase the amount of food available they chose plants or animals with improved characteristics to breed, or "cross," for the next generation. For example, they might have crossed one plant with higher yields to another plant that had increased pest resistance and then screened the plants resulting from the cross to find ones with both higher yield and better pest tolerance. Virtually every food in today's market has been modified in this way and, as a result, most foods we eat today look little like their ancient relatives.

\section{What happens when two plants or animals are bred?}

Living organisms are made up of large numbers of individual cells that contain genetic information specifying what traits the organism will have, such as purple or red fruit, lean or fatty meat, tolerance or susceptibility to disease. That information, contained in a small compartment of the cell called a nucleus, is in discrete packets called chromosomes. Chromosomes are made up of long strings of DNA, which is made up of individual chemical units that form unique pieces of information, called genes that are responsible for specific characteristics.

The entire collection of genes in an individual organism is like a collection of books with entries about many topics. The entries, or genes, in the books describe exactly what features the organism will have. Each plant species (related plants that can interbreed) has its own set of books. While many entries, or genes, in the collection are similar to those in other organisms, some are different, but the entire collection of books is written in the same language. For a given plant, such as rice, the entire collection of books is called a genome. Groups of books represent a chromosome and an entry or gene is equivalent to half a page of information in the book.

The genetic information in the cell is made up of individual chemical units, collectively known as DNA. If an alphabetic letter were used to represent each chemical unit in the genome, it would require a collection of approximately 40 books, each book having 1,000 pages, to contain all of the information in a rice cell. In 2005, the complete genome of rice was determined and found to contain approximately 37,500 genes, more than were identified in the human genome.

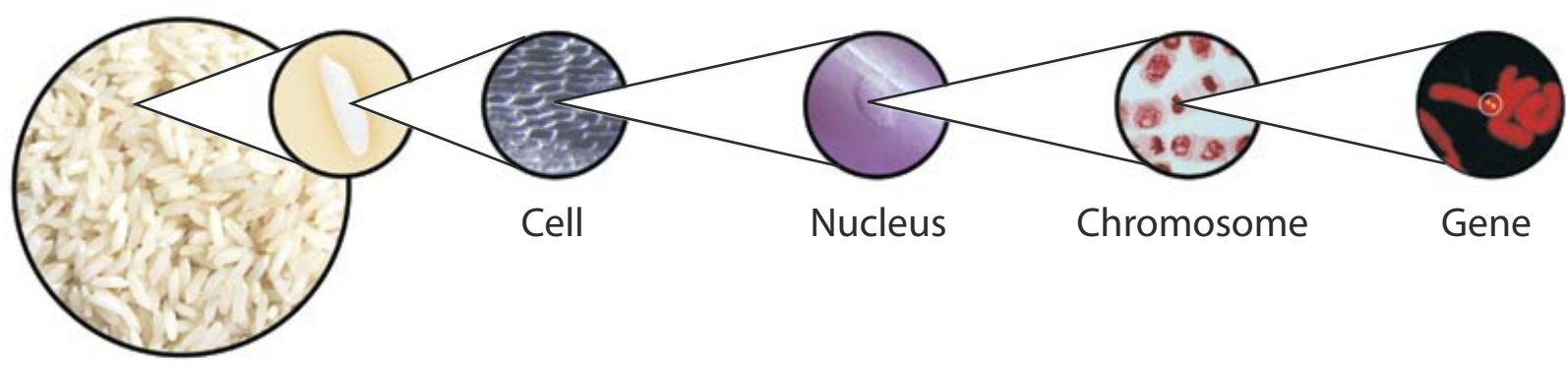




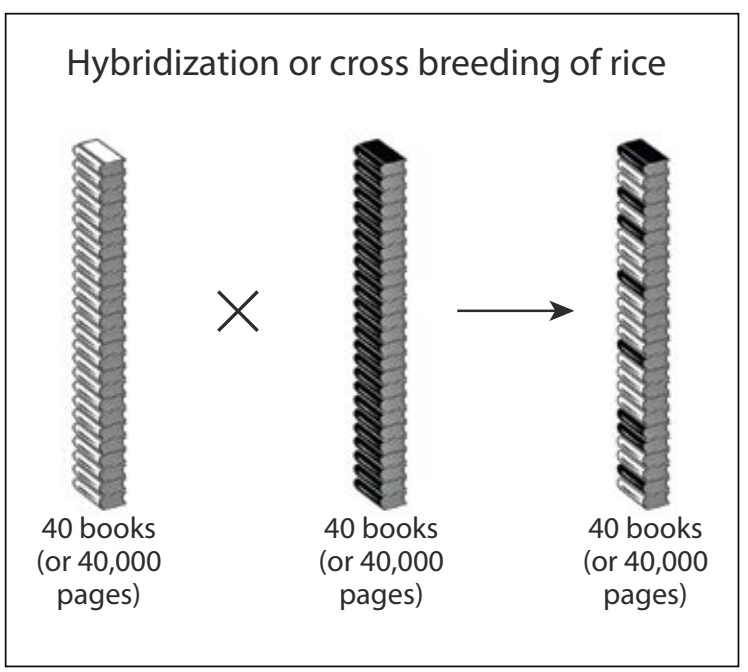

\section{How can classical breeding be used to create new crop varieties?}

What happens to this genetic information when we cross two rice plants? Does the next generation of plants end up with 80 books in the collection? No. Genetic rules state that progeny can only have the same number as the parent, 40 in the case of rice. So some pieces of information or genes from each parent are kept and some are lost, yielding a plant with new characteristics. Historically, the breeder, be it a human or an insect, has little direct control over which genes are kept and which are lost. For example, a breeder could cross the male cells (pollen) of one plant with the female cells (eggs) of another plant, observe the outcome, and choose the plants with the desired traits for the next round of breeding. This process, called classical breeding, results in plants with modified genomes and new mixes of genes.

\section{How is marker-assisted selection used to improve crop varieties?}

There are several different ways that new genetic tools can be used to change the genetic makeup of plants and animals. In one case, called marker-assisted selection (MAS), the genome of the plant or animal is "read" and a "table of contents" is developed that can be used by the breeder to determine if a particular characteristic from one of the parents is in a progeny plant. It is like using the "find" command in a word processing system to find a particular series of words in a book; those words can then help you find a given chapter. In breeding, chemical tags can be used to determine whether the desired genetic information is in a particular plant. If the chemical tags, or "the words," are found, you are likely (although not certain) to have found a particular trait in the plant. This process enables breeders to develop new varieties more efficiently than with the more "observational" classical breeding approach described previously. For example, researchers in Mexico used MAS to improve both drought and viral tolerance in maize (Ribaut et al. 2001).

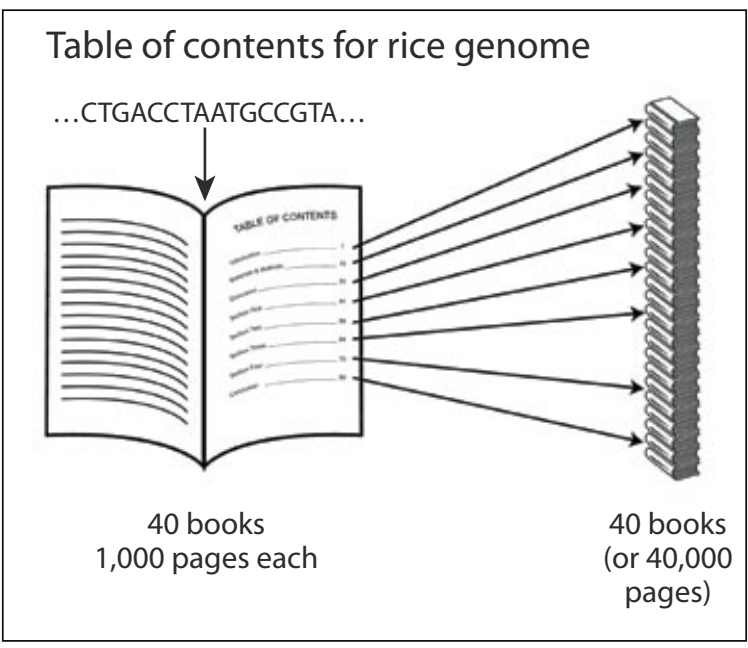

\section{How is genetic engineering used to change crop varieties?}

Another method used to improve the genetic makeup of plants involves the direct use of the new recombinant DNA methods; the process is also referred to as genetic engineering (GE). These methods allow researchers to modify the genes in plants in a more directed way than with classical breeding. In this case, the "molecular breeder" can look at a specific piece of genetic information, or a gene, from any living organism, cut out the desired gene with "chemical scissors" and "paste" it into the genetic material of the same organism or a different one.

How are the two methods, classical breeding and genetic engineering, used to modify crop plants and animals? To answer this question, let's look at two different ways to increase the sugar content of the commercial tomato, a goal made possible by the fact that some wild tomato varieties, although quite different in taste and looks, have a higher sugar content (see Bennett et al. 1994). 
In the classical breeding approach, breeders crossed the two varieties hoping to get a tomato with higher sugar content but none of the undesirable characteristics of the wild tomato, like smaller size, bitter taste, and lower yield. After many years of crossing back to the commercial tomato, they got a tomato with higher sugar content. In the analogy, they crossed the two collections of books; in the case of tomato each collection contained 102 books, or 102,000 pages, since the genome is slightly larger than rice. The plants resulting from the original cross were bred back to the commercial variety to increase the amount of information from that variety. After numerous crosses back to the commercial tomato, finally most of the "information" or genes came from the commercial tomato. But the collection still contained about 100 to 200 pages from the wild species. In those 100 to 200 pages was the information for the higher sugar trait they wanted, but also information for lower fertility, something they didn't want. This occurred because they were not able to "read" and select against the other information in the remaining 100 to 200 pages.

Genetic engineering methods

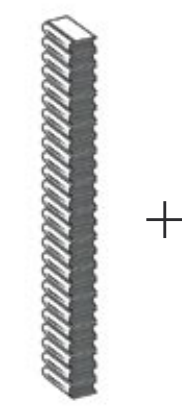

40 books (or 40,000 pages)

In the genetic engineering approach, researchers looked at the pages of information in the tomato fruit and found a gene, equivalent to half of a page of information, that is responsible for sugar breakdown. This gene was removed by cutting it from the genome with "chemical scissors" and inserting a reverse copy of the gene back into the tomato. Because of the presence of the reverse copy the cell had difficulty breaking down the sugar, and this made the tomato sweeter. In this approach they changed only a half page of information in the nearly 80,000 pages that represent the tomato genome and inserted only the specific information needed. This avoided the consequence of the undesired fertility decrease seen with the classical breeding approach.

\section{Are classical breeding and genetic engineering the same or different?}

In both approaches genetic information in a cell is changed or modified, and the exchange uses the same genetic machinery. In the case of classical breeding in plants, gene transfer occurs largely through cross-pollination within a single species (by definition, organisms that can interbreed); however, genetic engineering requires a laboratory step, and in this process genes from any organism can be introduced into a plant. In this sense genetic engineering is both similar to and different from classical breeding.

There are other differences. First, genetic engineering methods involve the specific handling of single genes, whereas with classical breeding thousands of genes are exchanged and rearranged. Second, with genetic engineering it is possible to control precisely where and when the new product is made. For example, as a food source sweetness need occur only in the tomato fruit, not in the leaves or roots. Lastly, and perhaps most importantly to some people, the half-page of information used in genetic engineering can be from any organism. It need not be closely related, as is the case with classical methods, because all genetic information regardless of its source-plant, animal, or microbe-is written in the same language.

\section{How are plants genetically engineered?}

Creation of genetically engineered plants depends on a unique characteristic of plants. Plant cells can be taken from any part of a plant and, with appropriate "coaxing," made to multiply and ultimately give rise to an entire plant. If a new gene is introduced into a plant cell, and the cells containing the new gene multiply, then that cell can give rise to an entire plant, each cell of which contains the new information. 
But exactly how is this done? A part of a plant, such as a leaf or a seed, is removed and a gene is then introduced into a small number of cells in that part, either by biological or physical methods (see Federoff and Brown 2004). The biological method uses a microorganism, Agrobacterium, a natural inhabitant of the soil, which inserts its DNA into the plant's genome. Scientists learned how to put other genes into the inserted DNA and then let Agrobacterium do the work of stably introducing the new gene. Another method involves using microscopic, DNA-coated "bullets" propelled at high speeds that end up inside the cell, where the DNA comes off and inserts itself into the plant's genome.

Once DNA is introduced, the researcher selects for cells that received the DNA. This can be done through the introduction of a gene that gives a selective advantage to the engineered cell. These genes can result, for example, in resistance to herbicides or antibiotics, or they can allow cells to grow under nutritional conditions that the nonengineered cell cannot. The next challenge is to "coax" the cells to reform a plant, through manipulating the hormones in the growth medium. Once this is done, a complete plant grows, each cell of which contains the new gene.

\section{What GE crops are out there?}

Introducing new genes into plants can involve using information from the same plant, a different plant, or from a different organism, such as a microorganism. Some such products have already been commercialized, including insect-resistant varieties of cotton and corn, herbicide-tolerant soybean, corn, canola, and alfalfa, and virus-resistant papaya and squash. Other products still in development in university and private laboratories include plants with increased pest resistance, improved yield, better drought and salt tolerance, reduced antinutrients like allergens, increased antioxidants and micronutrients like folic acid and iron, and plants that serve as alternative sources of industrial oils and fuels and can remediate metal and organic pollutants from soils and water.

\section{PERSPECTIVE}

As with other technologies developed in the past, such as the domestication of plants and animals, agricultural mechanization, chemical fertilizers, and pesticides, the use of new genetic tools brings questions about risks and benefits. While few, if any, activities in today's technologically complex world involve zero risk, people look to minimize human and environmental risk. End-users and consumers must be knowledgeable about new technologies and their use and participate in informed debate about how they will be used.

\section{REFERENCES}

Bennett, A. B., R. T. Chetelat, and E. M. Klann. 1994. Exotic germplasm or engineered genes: Comparison of genetic strategies to improve tomato fruit quality. Abstract, American Chemical Society 208:AGFD 12.

Ribaut, J. M., J. Betran, K. Dreher, K. Pixley, and D. Hoisington. 2001. Markerassisted selection in maize: Strategies, examples and costs. Abstract, Plant and Animal Genome IX Conference W40 06.

\section{General Information}

Federoff, M., and N. M. Brown. 2004. Mendel in the kitchen: A scientist's view of genetically modified foods. Washington D.C.: Joseph Henry Press.

Institute of Medicine and National Research Council of the National Academies. 2004. Safety of genetically engineered foods: Approaches to assessing unintended health effects. Washington D.C.: National Academy Press. 
Ridley, M. 1999. Genome: The autobiography of a species in 23 chapters. New York: HarperCollins.

\section{FOR MORE INFORMATION}

To order or obtain printed ANR publications and other products, visit the ANR Communication Services online catalog at http://anrcatalog.ucdavis.edu. You can also place orders by mail, phone, or FAX, or request a printed catalog of our products from:

University of California

Agriculture and Natural Resources

Communication Services

6701 San Pablo Avenue, 2nd Floor

Oakland, California 94608-1239

Telephone: (800) 994-8849 or (510) 642-2431

FAX: (510) 643-5470

E-mail inquiries: danrcs@ucdavis.edu

An electronic version of this publication is available on the ANR Communication Services Web site at http://anrcatalog.ucdavis.edu and on the UC ANR Biotechnology Workgroup Web site, http://ucbiotech.org.

Publication 8178

(C) 2006 by the Regents of the University of California, Division of Agriculture and Natural Resources. All rights reserved.

The University of California prohibits discrimination or harassment of any person on the basis of race, color, national origin, religion, sex, gender identity, pregnancy (including childbirth, and medical conditions related to pregnancy or childbirth), physical or mental disability, medical condition (cancer-related or genetic characteristics), ancestry, marital status, age, sexual orientation, citizenship, or status as a covered veteran (covered veterans are special disabled veterans, recently separated veterans, Vietnam era veterans, or any other veterans who served on active duty during a war or in a campaign or expedition for which a campaign badge has been authorized) in any of its programs or activities. University policy is intended to be consistent with the provisions of applicable State and Federal laws.

Inquiries regarding the University's nondiscrimination policies may be directed to the Affirmative Action/Staff Personnel Services Director, University of California, Agriculture and Natural Resources, 1111 Franklin Street, 6th Floor, Oakland, CA 94607-5201, (510) 987-0096. For a free catalog of other publications, call (800) 994-8849. For help downloading this publication, call (530) 754-5112.

This publication has been anonymously peer reviewed for technical accuracy by University of California scientists and other qualified professionals. This review process was managed by the ANR Associate Editor for Animal, Avian, Aquaculture, and Veterinary Sciences.

Content is current as of July 2005.

pr-02/06-SB/CR

ISBN 978-1-60107-398-3 